\title{
Socio-Economic Metabolism and Sustainability at a Watershed
}

\author{
Angela Terumi Fushita, José Eduardo dos Santos \\ Department of Hydrobiology, Federal University of São Carlos, São Carlos, Brazil \\ Email: angela_fushita@yahoo.com.br
}

Received 25 October 2015; accepted 16 November 2015; published 19 November 2015

Copyright (C) 2015 by authors and Scientific Research Publishing Inc.

This work is licensed under the Creative Commons Attribution International License (CC BY). http://creativecommons.org/licenses/by/4.0/

(c) (i) Open Access

\section{Abstract}

This research relates to the change in land use and land cover and to socio-economic metabolism, which constitute two approaches to interdisciplinary research on the society-nature relationship. The study focuses on relationships between the spatial pattern of land use, as exhibited through changes in Human Appropriation of Net Primary Productivity percentage (HANPP\%), and socioeconomic indicators (such as social exclusion/inclusion, income autonomy, human development, social equity and quality of life) of census sectors of a watershed. The analysis seeks to identify the existence of ecological and economic conflicts as a means of diagnosing the sustainability condition of the mid-upper Mogi Guaçu River watershed in 2009. The spatial pattern of land use of the watershed in 2009 indicates that ecosystems and natural habitats had already been reduced to a fraction of their original sizes and that a significant portion of their primary productivity had been appropriated. The predominance of anthropogenic agricultural activities in the watershed was the main cause of the increase in the HANPP\%. Lower HANPP\% values are associated with census sectors in regions with legally protected conservation areas; higher values are associated with census sectors involved in anthropogenic agricultural and non-agricultural activities. A positive significant correlation was observed between HANPP\% and social exclusion/inclusion, income autonomy and human development indicators, with values above the Basic Social Inclusion Standard, indicating lower trophic availability. With the exception of the quality of life indicator, lower $(0.75$ to 0.25$)$ and higher $(-0.75$ to -0.25$)$ social exclusion values were observed in rural and urban census sectors. The environmental sustainability of the middle Mogi Guaçu River watershed has been compromised in terms of the amount of biomass available to the trophic community. However, socio-economic indicators demonstrate an improved quality of life for the populations of the census sectors of the middle Mogi Guaçu River watershed.

\section{Keywords}

HANPP, Sustainability Indicator, Socio-Economic Indicators, Land Use Change 


\section{Introduction}

Although changes in land use may create various types of cultural landscapes with ecological, economic and aesthetic value, they also cause the degradation and loss of soil and compromise the naturalness and diversity of ecosystems.

Changes in the landscape due to land use patterns alter the balance and dynamics of ecological processes. These changes create new spatial arrangements related to cultural practices and regional development [1] [2] and influence the society-nature relationship by reducing the natural capital that provides ecosystem services that enhance human well-being [3] [4].

The analysis of the socio-economic metabolism and energy flow of an environmental system in any temporal scale contributes to the understanding of the society-nature relationship. The interaction between indicators of energy and material flow and socio-economic indicators has been shown to be extremely compensatory at the regional and local levels (when such socio-economic data are available) [5]. These indicators contribute to the understanding of the extent of human activities in particular ecosystems and the potential effects thereof, focusing on the characteristics of development models and, consequently, on regional sustainability patterns [6].

Socio-economic metabolism refers to the manner in which society structures its growing demands for energy and materials with respect to the environment [7]. Although a significant correlation between land use and socio-economic metabolism has been observed [8], this relationship should be explicitly defined in order to determine the extent to which changes in land use lead to changes in socio-economic metabolism [9].

The sustainability condition of an environmental system requires maintenance of the exchange of vital physical processes between society and the natural environment, which ensures economic prosperity and social equity [5]. Measures related to socio-economic metabolism and the Human Appropriation of Net Primary Productivity (HANPP) permit an understanding of the sustainability condition in the context of the society-nature relationship. HANPP values describe the extent to which human activity has appropriated land use in a particular region [10] [11]. The relationships between HANPP and activities related to socioeconomic metabolism and between HANPP and land-use intensity in specific regions were well explored by [12]. Similarly, HANPP values demonstrate a sound correlation with landscape naturalness, which confirms the hypothesis of a close correlation between landscape patterns and processes [9].

The metabolic approach was adopted in this study to diagnose conflicts between socio-economic indicators and the pattern of spatial distribution of HANPP. Thus, this study contributes to knowledge on the interaction of ecological and socio-economic goals and to the development of land-use policies that aim to preserve the sustainability of watersheds.

\section{Materials and Methods}

\subsection{Study Area}

The study area covers 429,700 ha and encompasses the mid-upper Mogi Guaçu River watershed located in northeastern São Paulo State, Brazil, between the geographical coordinates $21^{\circ} 20^{\prime}$ and $22^{\circ} 5^{\prime}$ South latitude and $47^{\circ} 16^{\prime}$ and $48^{\circ} 12^{\prime}$ West longitude. The watershed includes the entire municipalities of Santa Rita do Passa Quatro, Luis Antônio, Guatapará, Rincão, Santa Lucia, Cravinhos and Américo Brasiliense and portions of the municipalities of Ibaté, Araraquara, São Carlos, Descalvado, Porto Ferreira and São Simão. It also encompasses two legally protected conservation areas: Jataí Ecological Station and Vassununga State Park (Figure 1).

\subsection{Methodological Procedures}

The spatial pattern of land use and land occupation in the watershed was obtained through on-screen digitalization of the image obtained from Landsat-5 sensor TM, orbit 220, point 75, dated 24 May 2009, RGB composite of bands 5,4 and 3 .

The land use and land cover typologies were differentiated at a primary hierarchical level based on shade, texture and context criteria [13] [14] by object oriented classification method through visual interpretation using MapInfo 10. Each polygon was previously related to a type of land use and land cover that was classified based on the decrease in landscape naturalness [15].

Human appropriation of net primary production (HANPP) is considered an indicator of the pressure of human activity on an ecosystem. HANPP reflects current and potential ecosystem processes and the fundamental com- 


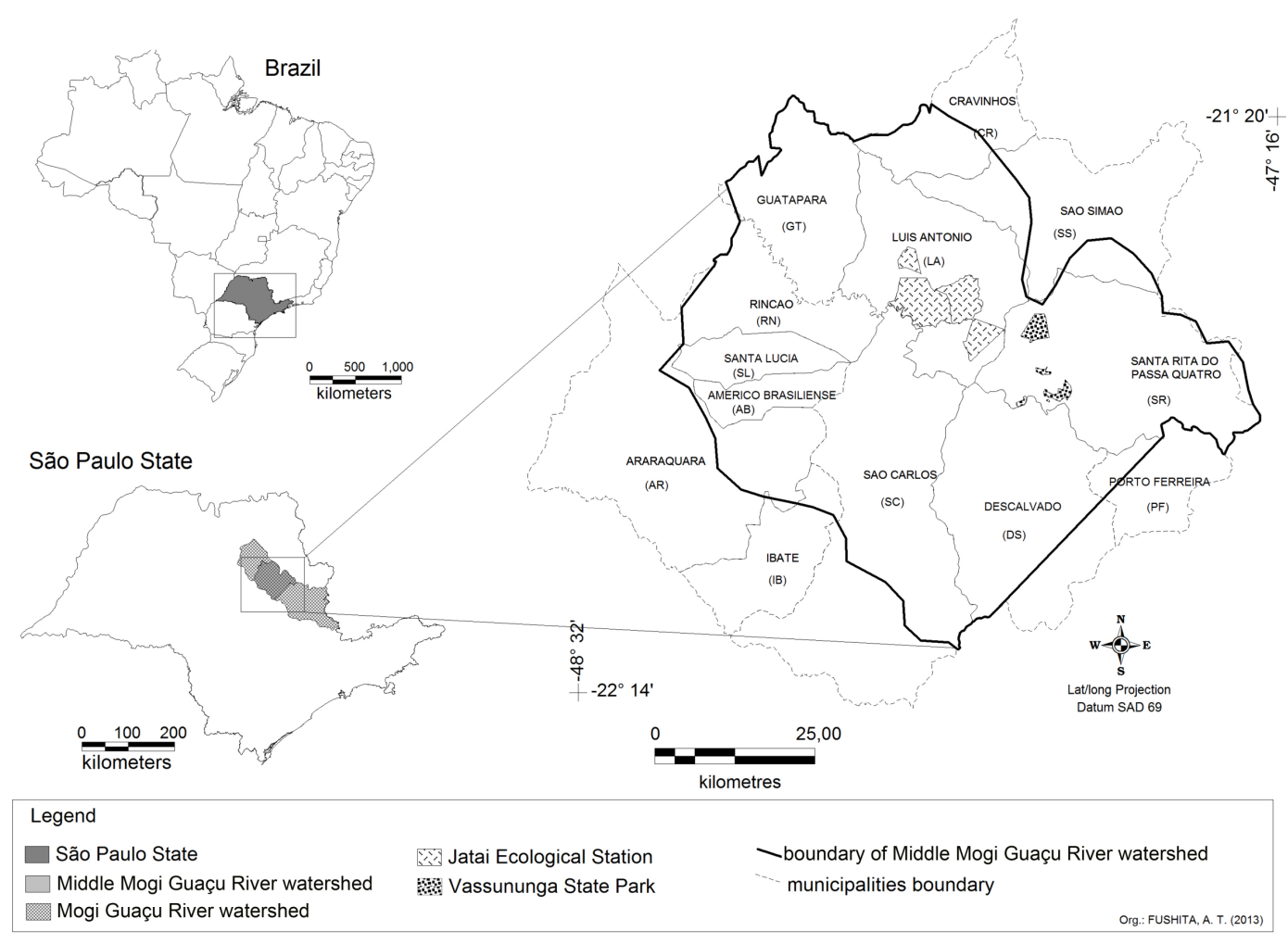

Figure 1. Location of the middle Mogi Guaçu River watershed, northeastern São Paulo State, Brazil. This figure shows the territories of the municipalities (12) and the legally protected conservation areas (2) included in the watershed.

ponents of socio-economic metabolism [16]. Specifically, HANPP calculates the percentage of the primary productivity of an ecosystem that has been appropriated by humans based on the dynamic global vegetation model in combination with vegetation modeling, agriculture and forestry statistics as well as land-use data from a geographical information system [17].

HANPP values were obtained by the combined effect of harvest and productivity changes induced by land use on the availability of Net Primary Productivity (NPP) in ecosystems. That is, HANPP is calculated as the difference between the NPP of potential vegetation $\left(\mathrm{NPP}_{0}\right)$, i.e., the plant cover that would prevail in the absence of human intervention and the fraction of NPP after remaining in ecosystems harvest (NPP lucc) [5] [10] [11].

$\mathrm{NPP}_{0}$ was calculated using the Chikugo model [18], which considers the temperature and rainfall of the study area. This model is expressed by Equation (1) and Equation (2).

$$
\begin{aligned}
& \mathrm{NPP}_{\mathrm{R}}=30\left[1-\exp ^{(-0.00065 R)}\right] \\
& \mathrm{NPP}_{\mathrm{T}}=\frac{30}{\left[1+\exp ^{(1.315-0.119 T)}\right]}
\end{aligned}
$$

where: $\mathrm{P}$ = annual rainfall $(\mathrm{mm})$,

$\mathrm{T}=$ annual temperature $\left({ }^{\circ} \mathrm{C}\right)$.

$\mathrm{NPP}_{\text {lucc }}$ is calculated by subtracting the amount of NPP harvested or destroyed during harvest $\left(\mathrm{NPP}_{\mathrm{h}}\right)$ from the NPP of actual prevailing vegetation $\left(\mathrm{NPP}_{\mathrm{act}}\right)$ [5] [10] [11].

$\mathrm{NPP}_{\text {act }}$ was generated based on the Normalized Difference Vegetation Index (NDVI) that is calculated from near-infrared and visivel spectral reflectance (Equation (3)) of LandSat imagery, and global solar radiation data [19] obtained by the National Institute of Meteorology.

$$
\mathrm{NDVI}=\frac{(\mathrm{NIR}-\mathrm{VIS})}{(\mathrm{NIR}+\mathrm{VIS})}
$$


where: NDVI = Normalized Difference Vegetation Index,

NIR = spectral reflectance measurements acquired in the near-infrared band,

VIS = spectral reflectance measurements acquired in the visible (red) band.

The NPP ${ }_{\text {act }}$ model is expressed by Equation (4) and consider the light efficiency factor varies as a function of the NDVI range of the pixel

$$
\mathrm{NPP}=\varepsilon \sum[(-0.31+1.31 \mathrm{NDVI}) \mathrm{RAD}]
$$

where: $\mathrm{NPP}_{\text {act }}=$ Net Primary Productivity after remaining in ecosystems harvest,

NDVI = normalized difference vegetation index,

$\mathrm{RAD}=$ global solar radiation,

$\varepsilon=$ efficiency fator of light.

The $\mathrm{NPP}_{\mathrm{h}}$ information was complemented by agricultural data [20]. The dead biomass of seasonal crops was considered fully appropriated $\mathrm{NPP}_{\mathrm{h}}$. In contrast, perennial crops were considered only partially appropriated because portions of the plants (such as the roots and branches) survive and produce another crop.

Regarding the $\mathrm{NPP}_{\text {lucc }}$ values, a change in the land-cover type that modifies the amount of NPP available to the trophic community is considered an indirect appropriation of NPP [21].

HANPP, thus, is the sum of $\mathrm{NPP}_{\text {lucc }}$ and $\mathrm{NPP}_{\mathrm{h}}$, where $\mathrm{NPP}_{\text {lucc }}$ denotes the impact on NPP of human-induced land conversions, such as land cover change, land use change, and soil degradation. HANPP was estimated as the difference between $\mathrm{NPP}_{0}$ and $\mathrm{NPP}_{\text {act }}$ after the appropriation of $\mathrm{NPP}_{\mathrm{h}}$, i.e., the sum of $\mathrm{NPP}_{\text {lucc }}$ and $\mathrm{NPP}_{\mathrm{h}}$ [5]. HANPP\% expresses HANPP as a percentage of $\mathrm{NPP}_{0}$.

The socioeconomic status of each census sector of the watershed was assessed using four indicators that are considered components of the social exclusion/inclusion indicator: income autonomy, human development, social equity and quality of life [22]-[24].

Income autonomy refers to the ability of individuals to manage their livelihoods based on the availability of economic resources. Human development includes variables related to the education and life expectancy of individuals. Social equity reflects conditions that favor the battle against subjugation or prejudice based on differences in political beliefs, ethnicity, religion and gender, among other attributes. Quality of life considers the following factors: the basic infrastructure of public and/or private housing (e.g., water supply and sewage and waste collection); the comfort of residences (number of residents per residence); and the property and condition of private residences [22].

The value of each indicator is derived from the aggregation of a set of variables related to the census sectors of the watershed, which are available from a geographic database [20]. The variables were operationalized on a scale from -1 to +1 , which correspond to the extremes of maximum social exclusion $(-1)$ or maximum social inclusion (+1). The value zero refers to the basic social inclusion standard of living (SIS), i.e., the minimum required for social inclusion [23].

The social exclusion/inclusion indicator (SIS) is generated by the aggregation and rescaling of the indicators for income autonomy, human development, social equity and quality of life, using the percentages and the sum of the variables that compose each indicator [22].

The spatial distribution of HANPP\% and the socioeconomic indicators were operationalized in ARC GIS 10.2. The correlation between socioeconomic indicators and HANPP\% was analyzed using Spearman's $\mathrm{r}$ correlation [25]. A confidence level of 0.05 and the null hypothesis $\mathrm{H}_{0}=$ no association between HANPP\% and the socioeconomic indicators (income autonomy, human development, social equity, quality of life and social inclusion/exclusion) were adopted.

\section{Results and Discussion}

At a primary hierarchical level, four types of land use were identified and quantified for the middle Mogi Guaçu River watershed in 2009: aquatic, anthropogenic agricultural, anthropogenic non-agricultural and forests (Figure 2).

Land characterized by anthropogenic agricultural uses include areas that were intentionally established for agricultural activities and that are dependent on human control and management. Anthropogenic agricultural areas occupy approximately $77 \%$ of the total area of the watershed, with a predominance of sugarcane cultivation, which is the main driving force of change in the watershed. 


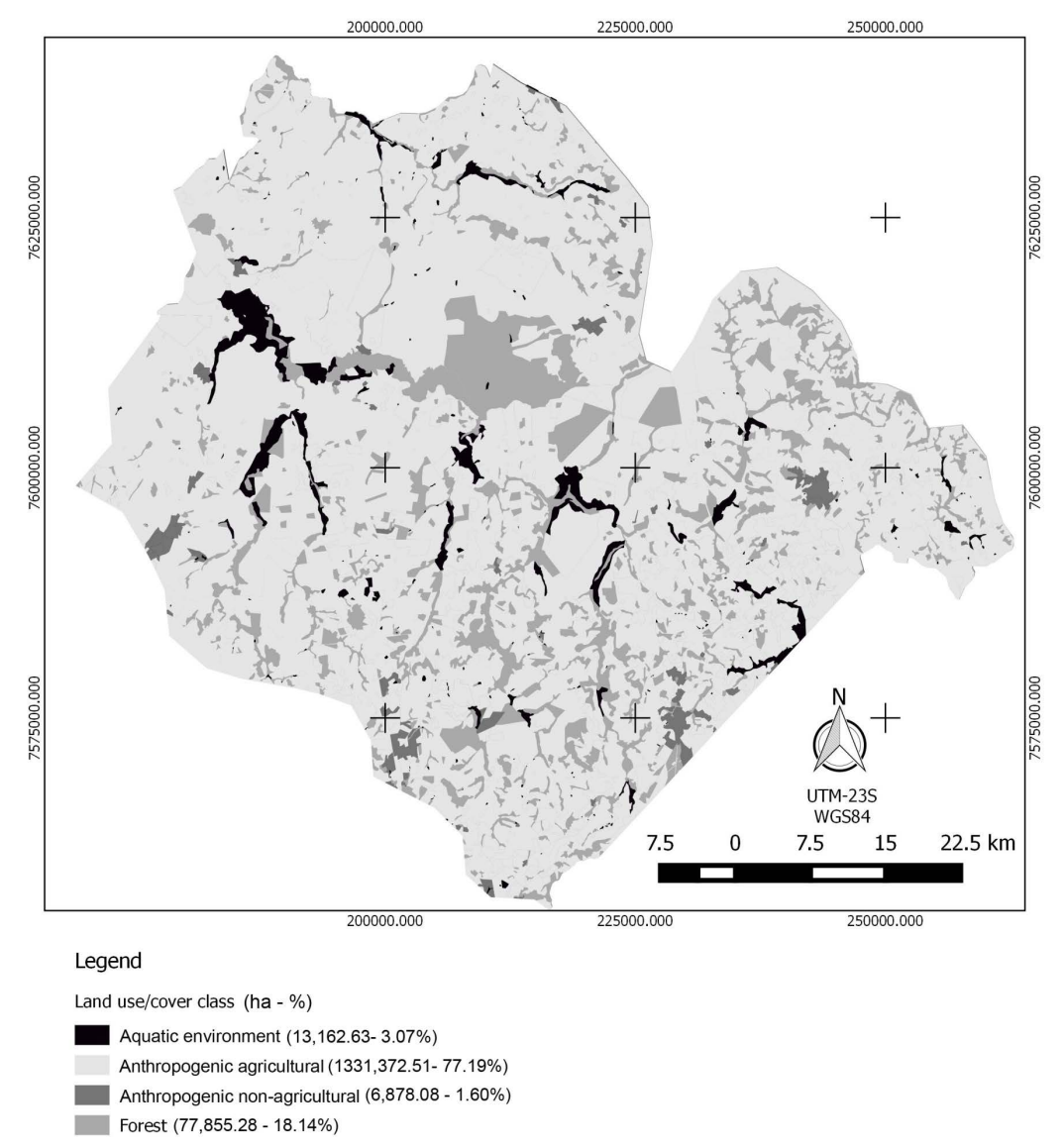

Figure 2. Spatial distribution and corresponding areas (ha and \%) of the land-use types in the middle Mogi Guaçu River watershed in 2009.

The forested area, which occupies approximately $18 \%$ of the watershed, is being transformed and replaced over time by anthropogenic agricultural and non-agricultural systems, leading to a loss of biodiversity and compromising the provision of ecosystem services. The transformation of the life support system into anthropogenic systems influences the environmental sustainability of the watershed. However, the prevalence of this landscape spatial pattern results in an increase in other environmental services, which leads to substantial gains in human well-being and regional economic development.

The spatial distribution of the area extensions and the HANPP\% values of the middle Mogi Guaçu River watershed are represented in Figure 3. This figure illustrates the physical areas and percentages of the NPP appropriated by human activities and the NPP that remained available to the trophic community as a result of the type of land use and land cover in the watershed in 2009. Although HANPP\% intervals between $0 \%$ and $20 \%$ and above $80 \%$ were observed, most HANPP\% values were between $50 \%$ and $70 \%$. Values between $20 \%$ and $30 \%$ represent approximately $3 \%$ of the watershed area.

The mean HANPP\% value (52\%) for the middle Mogi Guaçu River watershed indicates that less than $48 \%$ of the biomass in this area remains available to the trophic community, which can be considered insufficient for the maintenance of ecosystem services and the sustainability of the watershed.

In general, lower HANPP\% values in the watershed are associated with census sectors in which legally protected conservation areas are located, whereas higher values are associated with census sectors occupied by anthropogenic agricultural and non-agricultural activities. The forest remnants and legally protected areas have HANPP\% values lower than $40 \%$ (Figure 3), which vary depending on the areas' proximity to locales disturbed by humans and on their respective regenerative stages.

The total appropriation (100\%) of the NPP of an area only occurs through drastic changes in land cover resulting from agricultural expansion or urbanization [12] [21]. 


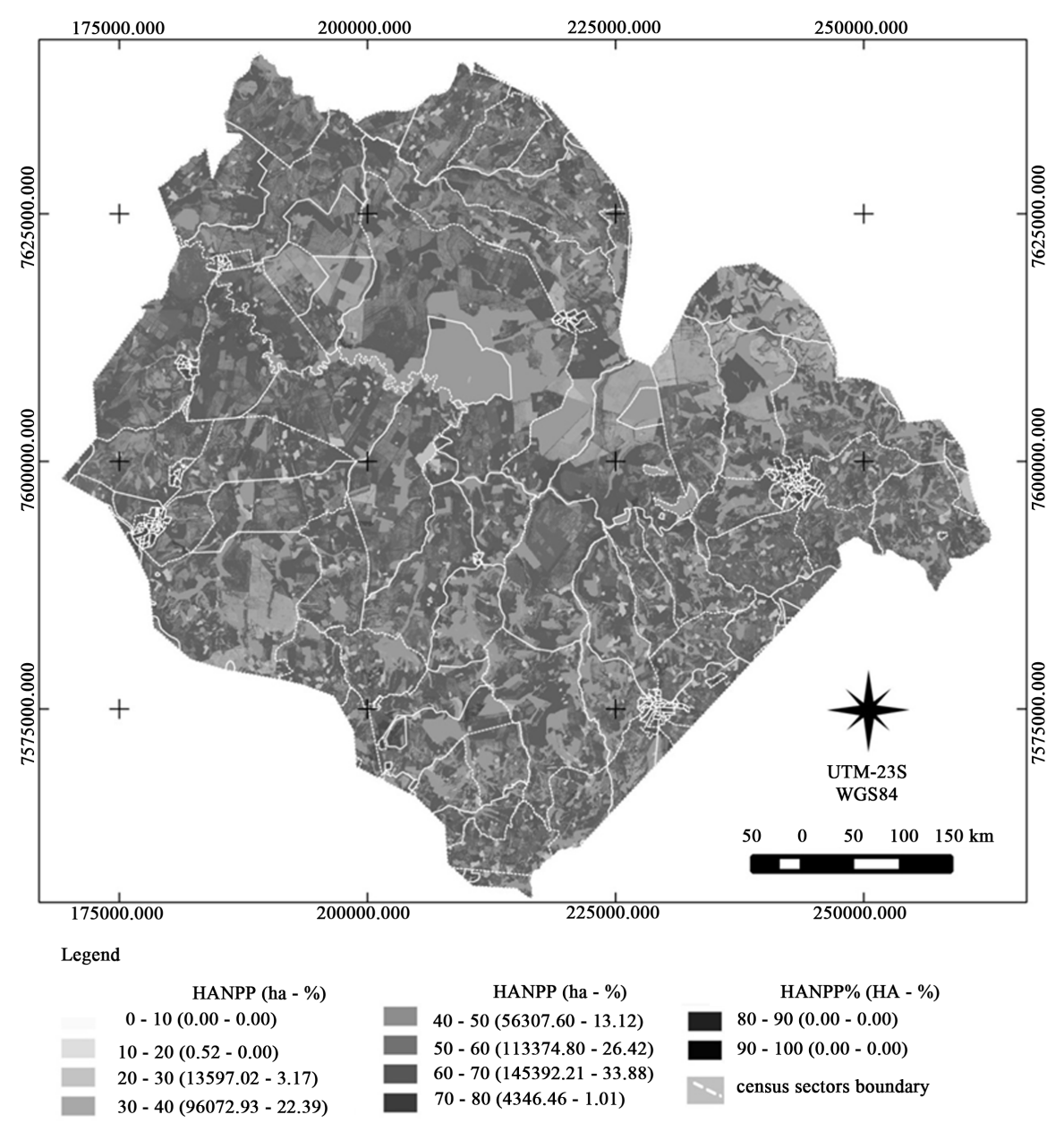

Figure 3. Spatial distribution gradient of the maximum (100\%) and minimum (0\%) Human Appropriation of Net Primary Productivity (HANPP\%) in the different census sectors of the middle Mogi Guaçu River watershed (São Paulo, Brazil) in 2009. HANP values are represented based on the extent (ha and \%) of the areas of human appropriation of primary production.

The HANPP\% values of the middle Mogi Guaçu River watershed, estimated pixel by pixel, range from $14 \%$ to 58\% (Figure 3), which are similar to global HANPP values reported in other studies [16] [26].

Estimates of global HANPP\%, which have a mean value of 20\% [27], account for the influence of agriculture and silviculture but do not consider deforestation, shifting cultivation and the below-ground biomass in grasslands.

The appropriation of NPP doubled and even tripled during the 20th century in Asia, Africa and Latin America, whereas industrialized regions (such as mainland Europe and western Russia) exhibited only slight growth or even stabilization of HANPP\% since 1980. The global HANPP\% values obtained by [26] range from 16 to $23 \%$, with the exception of Asia, where HANPP\% is close to $45 \%$ due to the predominantly agricultural use of land and the high population density.

Previous global HANPP\% estimates of 31\% (with a range of 3\% to 39\%) [11] and 32\% (with a range of $10 \%$ to $55 \%$ ) [28] are close to the values obtained in this study.

HANPP\% values in Nova Scotia (Canada) ranged from 6 to 50\% during 1999-2003 due to the intensity of agricultural activities, which occupied between $3 \%$ and $8 \%$ of the total study area [21]. In contrast, more than $70 \%$ of the middle Mogi Guaçu River watershed is occupied by the cultivation of sugarcane for the production of ethanol (Figure 2). This watershed is a cultural landscape with a high HANPP\% that is exported beyond its borders.

The HANPP\% values obtained in this study were similar to values reported in studies on European countries 
[29]. However, the socioeconomic differences among the study areas and the context in which they are embedded should be considered. European countries have higher HANPP\% values because urbanized areas occupy a higher percentage of the territory ( $\mathrm{NPP}_{\text {lucc }}$ ), whereas the high HANPP\% values in the middle Mogi Guaçu River watershed are due to the appropriation of the plant biomass of agricultural crops $\left(\mathrm{NPP}_{\mathrm{h}}\right)$.

Figures 4(a)-(e) show the spatial distribution of socio-economic indicators related to social exclusion/inclusion for each census sector of the middle Mogi Guaçu River watershed. The analysis of these indicators focused on the identification of the minimum requirement for social inclusion (SIS), not the distance between the extremes of maximum social inclusion (+1) and maximum social exclusion $(-1)$. Thus, the SIS of the social exclusion/inclusion indicators, not the mean of the distribution of a resource, was evaluated [30].

SIS levels of the income autonomy, social equity, human development and social exclusion/inclusion indicators (Figures 4(a)-(c) and Figure 4(e)) are associated with census sectors that include forest remnants (Figure 4(f)) and lower HANPP\% values (Figure 3). These census sectors constitute islands embedded in a matrix of social exclusion. With the exception of the quality of life indicator, lower (values between 0.75 and 0.25 ) and higher (values between -0.75 and -0.25 ) social exclusion (Figure 4(a)-(c) and Figure 4(e)) was observed in rural census sectors with HANPP between $40 \%$ and 55\% and in urban census sectors with HANPP\% above $60 \%$ (Figure 3).

The extremes of social exclusion and inclusion identified based on the socio-economic indicators reflect greater appropriation of primary productivity, which in turn leads to a level of primary productivity that can be considered insufficient for the maintenance of ecosystem services and the sustainability of the watershed.

Values of the quality of life indicator that are close to the SIS, which corresponds to the minimum condition for social inclusion, are associated with rural census sectors, whereas values between -0.5 and -0.1 are associated with urban sectors, which are characterized by HANPP\% values above 50\% (Figure 4(d)). The quality of life values per census sector reflect better economic conditions relative to the national average, especially for rural census sectors, where household income per capita is above the national average [20].

A significant correlation was observed between HANPP\% values and socio-economic indicators for each census sector of the middle Mogi Guaçu River watershed. Specifically, there was a positive correlation between HANPP\% and the social exclusion/inclusion $(\mathrm{r}=0.279, p<0.0001)$, income autonomy $(\mathrm{r}=0.394, p<0.0001)$ and human development $(\mathrm{r}=0.332, p<0.0001)$ indicators and a negative correlation between HANPP\% and the social equity $(\mathrm{r}=-0.087, p=0.0015)$ and quality of life $(\mathrm{r}=-0.190, p=0.0016)$ indicators. Census sectors in which the social exclusion/inclusion, income autonomy and human development indicators are above SIS values are associated with lower trophic availability (higher HANPP\% values) due to land use (Figure 3 and Figure 4).

The environmental sustainability of the middle Mogi Guaçu River watershed has been compromised in terms of the biomass available for the trophic community and the maintenance of ecosystem services. However, the socio-economic indicators indicate an improved quality of life for the populations of the census sectors in the middle Mogi Guaçu River watershed.

\section{Final Considerations}

The approach presented in this study shows that socio-economic indicators and changes in land use provide a theoretical framework for the discussion of changes in the society-nature relationship in a watershed.

HANPP is positively correlated with the indicators for social exclusion/inclusion, income autonomy and human development, suggesting that as socio-economic conditions improve, the biomass available to the biodiversity of the middle Mogi Guaçu River watershed decreases.

The minimum conditions for social inclusion for the income autonomy, social equity, human development and social exclusion/inclusion indicators are associated with census sectors with forest remnants and the lowest HANPP\% values. These census sectors are islands within a matrix of social exclusion. With the exception of the quality of life indicator, lesser and greater social exclusion was observed for rural census sectors with HANPP\% values between $40 \%$ and $55 \%$ and for urban census sectors with HANPP values above $60 \%$.

The spatial pattern of land use in the middle Mogi Guaçu River watershed in 2009 resulted in the reduction of ecosystems and habitats to a fraction of their original sizes and the significant appropriation of their primary productivity. Thus, the transition to stable socio-economic conditions will not occur quickly enough to ensure the protection of the biodiversity islands (which are associated with legally protected areas), which indicates that habitat fragmentation and environmental degradation are associated with agricultural expansion and population growth, trends that are likely to continue in the immediate future. 

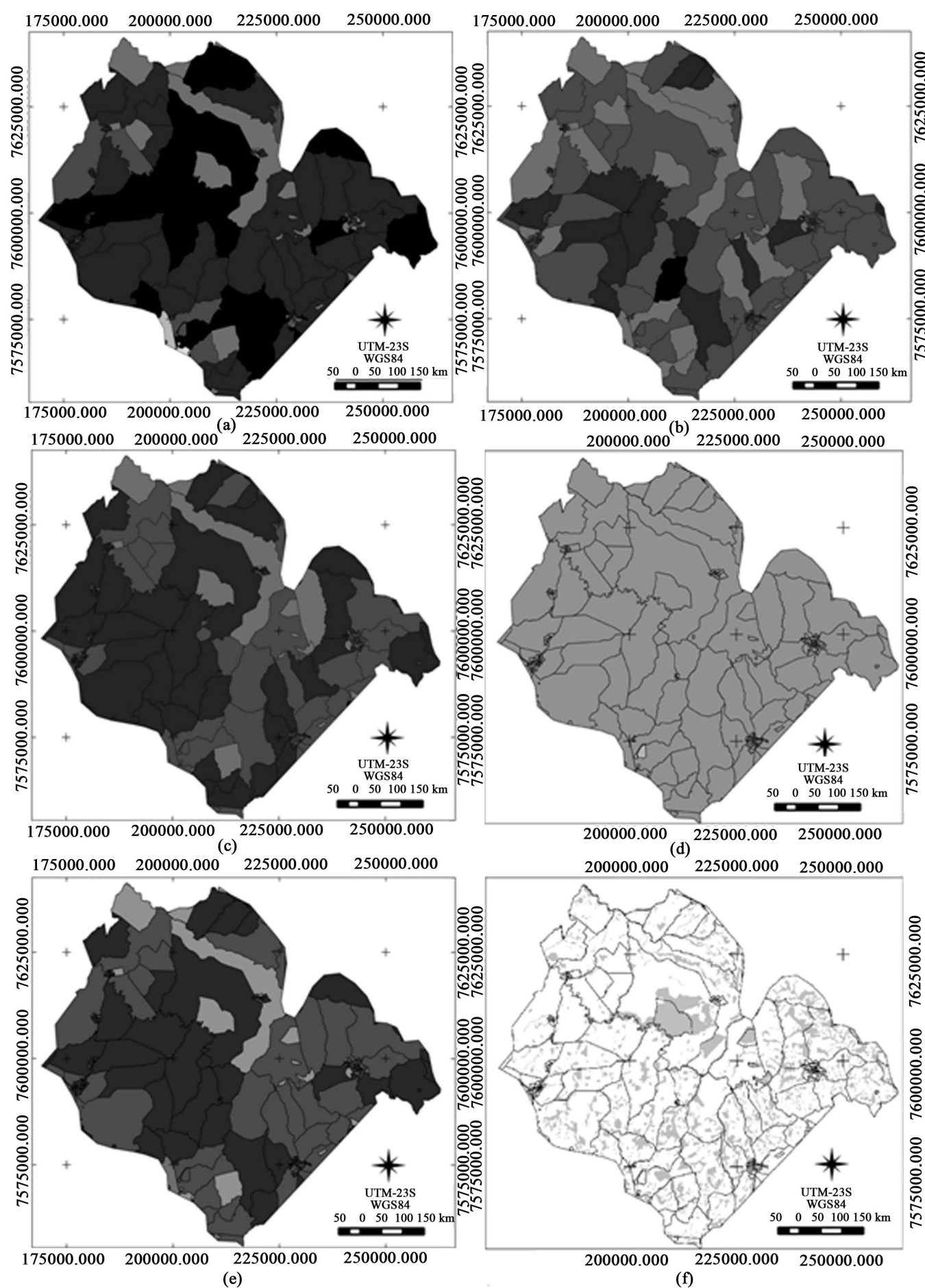

Legend

(e)

(f)

socio-economic indicators (a) to (e)

-1.00 to $-0.75 \square-0.50$ to $-0.25 \square 0.00$ to $0.25 \square 0.50$ to 0.75
-0.75 to $-0.50 \square-0.25$ to $0.00 \square 0.25$ to $0.50 \square 0.75$ to 1.00

vegetation cover (f)
vegetation fragments

Figure 4. Spatial distribution of the following socio-economic indicators for the various census sectors in the middle Mogi Guaçu River watershed: (a) Income autonomy; (b) Social equity; (c) Human development; (d) Quality of life and (e) Social exclusion/inclusion. Qualitative condition of natural vegetation in the census sectors of the mid-upper Mogi Guaçu River watershed in 2009 (f). 
The census sectors of the watershed are located in a regional and national economy that is supported by trade and communication networks that transport people, organisms, energy, materials and information and require a continuous supply of energy and materials. The transportation of goods and resources generates environmental impacts that are geographically distant from the watershed where the goods and resources originated and the primary productivity was appropriated. Therefore, the regional economy influences HANPP\% values, which in turn affects consumption and production efficiencies.

HANPP evaluates the environment by quantifying the amount of energy available to other species after appropriation by humans and is likely correlated with socio-economic parameters. Therefore, this measure allows inferences about the loss of biodiversity, the extent of landscape intervention and the factors that allow the prioritization of land based on ecosystem sustainability and on an understanding of the metabolic profile of the watershed.

\section{Acknowledgements}

Financial support was provided by the Coordination for the Improvement of Higher Education Personnel (CAPES).

\section{References}

[1] Perez-Soba, M., Petit, S., Jones, L., Bertrand, N., Briquel, V., Omodei-Zorini, L., et al. (2008) Land Use Functions-A Multifunctionality Approach to Assess the Impact of Land Use Changes on Land Use Sustainability. In: Helming, K., Perez-Soba, M. and Tabbush, P., Eds., Sustainability Impact Assessment of Land-Use Changes, Springer, Berlin, 375404. http://dx.doi.org/10.1007/978-3-540-78648-1 19

[2] Torres-Gómez, M., Delgado, L.E., Marín, V.H. and Bustamante, R.O. (2009) Landscape Structure along Gradients Urban-Rural in the River Basin Aisen (Aysen Region, Chile). Revista Chilena de Historia Natural, 82, 73-82.

[3] Haberl, H., Wackernagel, M. and Wrbka, T. (2004) Land Use and Sustainability Indicators. An Introduction. Land Use Policy, 21, 193-198. http://dx.doi.org/10.1016/j.landusepol.2003.10.004

[4] Millennium Ecosystem Assessment (2003) Ecosystems and Human Well-Being: A Framework for Assessment. Island Press, Washington DC.

[5] Haberl, H.M., Erb, K.H. and Krausmann, F. (2014) Human Appropriation of Net Primary Production: Patterns, Trends, and Planetary Boundaries. Annual Review of Environment and Resources, 39, 363-391. http://dx.doi.org/10.1146/annurev-environ-121912-094620

[6] Porto, M.F. and Martinez-Alier, J. (2007) Political Ecology, Ecological Economics and Public Health: Interfaces for the Sustainability of Development and Health Promotion. Cadernos de Saúde Pública, 23, S503-S512.

[7] Martinez-Alier, J., Kallis, G., Veuthey, S., Walter, M. and Temper, L. (2010) Social Metabolism, Ecological Distribution Conflicts, and Valuation Languages. Ecological Economics, 70, 153-158. http://dx.doi.org/10.1016/j.ecolecon.2010.09.024

[8] Riebsame, W., Meyer, W.B. and Turner II, B.L. (1994) Modeling Land Use and Cover a Part of Global Environmental Change. Climatic Change, 28, 45-64. http://dx.doi.org/10.1007/BF01094100

[9] Krausmann, F., Haberl, H., Schulz, N., Erb, K.H., Darge, E. and Gaube, V. (2003) Land-Use Change and Socioeconomic Metabolism in Austria. Part I: Driving Forces of Land-Use Change 1950-1995. Land Use Policy, 20, 1-20. http://dx.doi.org/10.1016/S0264-8377(02)00048-0

[10] Haberl, H. (2006) The Global Socioeconomic Energetic Metabolism as a Sustainability Problem. Energy, 31, 87-99. http://dx.doi.org/10.1016/j.energy.2004.04.045

[11] Vitousek, P.M., Mooney, H.A., Lubchenco, J. and Mclillo, J.M. (1997) Human Domination of Earth’s Ecosystems. Science, 277, 494-499. http://dx.doi.org/10.1126/science.277.5325.494

[12] Wrbka, T., Erb, K.H., Schulz, N.B., Peterseila, J., Hahna, C. and Haberl, H. (2004) Linking Pattern and Process in Cultural Landscapes. An Empirical Study Based on Spatially Explicit Indicators. Land Use Policy, 21, 289-306. http://dx.doi.org/10.1016/j.landusepol.2003.10.012

[13] Crosta, A.P. (1992) Remote Sensing Digital Image Processing. Campinas IG/UNICAMP, 173 p.

[14] Moreira, M.A. (2011) Remote Sensing Fundamentals and Application Methods. 4th Edition, UFV, Brazil, 422 p.

[15] Haber, W. (1994) Systems Ecological Concepts for Environmental Planning. In: Klijn, F., Ed., Ecosystem Classification for Environmental Management, Leiden University, Leiden, 49-67.

http://dx.doi.org/10.1007/978-94-017-1384-9 3 
[16] Field, C.B., Campbell, E. and Lobell, D.B. (2007) Biomass Energy: The Scale of the Potential Resource. Trends in Ecology and Evolution, 23, 65-72. http://dx.doi.org/10.1016/j.tree.2007.12.001

[17] Abson, D.J., Dougill, A.J. and Stringer, L. (2012) Using Principal Component Analysis for Information-Rich SocioEcological Vulnerability Mapping in Southern Africa. Applied Geography, 35, 515-524. http://dx.doi.org/10.1016/j.apgeog.2012.08.004

[18] Uchijima, Z. and Seino, H. (1985) Agroclimatic Evaluation of Net Primary Productivity of Natural Vegetations. Journal of Agricultural Meteorology, 40, 343-352. http://dx.doi.org/10.2480/agrmet.40.343

[19] Nascimento, R.S., Brito, J.I.B. and Braga, C.C. (2009) Estimating Net Primary Production Using NDVI Data for the State of Paraiba. Anais do XIV Simpósio Brasileiro de Sensoriamento Remoto, Natal, 25-30 April 2009, 5321-5327.

[20] IBGE (2010) Demographic Census. http://censo2010.ibge.gov.br/

[21] O’Neill, D.W., Tyedmers, P.H. and Beazley, K.F. (2007) Human Appropriation of Net Primary Production (HANPP) in Nova Scotia, Canada. Regional Environmental Change, 7, 1-14. http://dx.doi.org/10.1007/s10113-006-0021-1

[22] Sposati, A. (1996) Social Exclusion/Inclusion Map of the City of São Paulo. EDUC, São Paulo.

[23] Genovez, P.C., Monteiro, A.M. and Câmara, G. (2007) Territorial Indicators of Inclusion/Exclusion: Geoinformation to Support the Planning of Social Policies. In: Almeida, C.M., Câmara, G. and Monteiro, A.M., Eds., Geoinformation in Urbanism: Real City x Virtual City, Oficina de Textos, São Paulo, 209-229.

[24] Nascimento, E. and Matias, L.F. (2008) Mapping Social Exclusion/Inclusion in Intra-Urban Space Based on Census Data: The Experience of Ponta Grossa, Paraná State, Brazil. TerraPlural, 2, 87-102. http://dx.doi.org/10.5212/TerraPlural.v.2i1.087102

[25] R CORE TEAM (2013) R: A Language and Environment for Statistical Computing. R Foundation for Statistical Computing, Vienna, Austria. http://www.R-project.org/

[26] Krausmann, F., Erb, K.H., Gingrich, S., Haberl, H., Bondeau, A., Gaube, V., et al. (2013) Global Human Appropriation of Net Primary Production Doubled in 20th Century. Proceedings of the National Academy of Sciences of the United States of America, 110, 10324-10329. http://dx.doi.org/10.1073/pnas.1211349110

[27] Imhoff, M.L., Bounoua, L., Ricketts, T., Loucks, C., Harriss, R. and Lawrence, W.T. (2004) Global Patterns in Human Consumption of Net Primary Production. Nature, 429, 870-873. http://dx.doi.org/10.1038/nature02619

[28] Rojstaczer, S., Sterling, S.M. and Moore, N.J. (2001) Human Appropriation of Photosynthesis Products. Science, 294, 2549-2552. http://dx.doi.org/10.1126/science.1064375

[29] Haberl, H., Gaube, V., Diaz-Delgado, R., Krauze, K., Neuner, A., Perterseil, J., et al. (2009) Towards an Integrated Model of Socioeconomic Biodiversity Drivers, Pressures and Impacts. A Feasibility Study Based on Three European Long Term Socio-Ecological Research Platforms. Ecological Economics, 68, 1797-1812. http://dx.doi.org/10.1016/j.ecolecon.2008.11.013

[30] Sposati, A. (2002) Social Exclusion/Inclusion Map. ComCiência.

\section{Abbreviation Note List}

HANPP: Human Appropriation of Net Primary Production

NPP: Net Primary Productivity

$\mathrm{NPP}_{0}$ : Net Primary Productivity of Potential Vegetation

$\mathrm{NPP}_{\text {lucc }}$ : Net Primary Productivity after remaining in ecosystems harvest

$\mathrm{NPP}_{\mathrm{h}}$ : Net Primary Productivity harvested or destroyed during harvest

$\mathrm{NPP}_{\text {act }}$ : Net Primary Productivity of actual prevailing vegetation

NDVI: Normalized Difference Vegetation Index

SIS: Social Exclusion/Inclusion Indicator 